\title{
En «clavemanía»: ¿Dónde están las llaves de... Sefarad?
}

Pilar Romeu Ferré*

Editorial Tirocinio

ORCID ID: http://orcid.org/0000-0002-9640-4952

Este artículo pretende contribuir a esclarecer el auge de la aparición de tantas «llaves» de las casas que los antepasados de los sefardíes poseían en la Península Ibérica antes de la expulsión de 1492, reconstruyendo los datos extraídos de periódicos y escritos de diversa índole a través de los siglos.

Palabras Clave: Sefarad; judíos sefardíes; Imperio otomano; llaves; literatura sefardí.

The «Madness» for Keys: ¿Where Are the Keys from... Sefarad?.- This paper aims to contribute to clarify the appearance of a growing number of «keys» from the houses that the Sephardic ancestors possessed in the Iberian Peninsula before the expulsion of 1492 , rebuilding the data relying on newspapers and writings from various kinds.

Keywords: Sepharad; Sephardic Jews; Ottoman Empire; Keys; Sephardic Literature.

\section{1. ¿DÓNDE ESTÁN LAS LLAVES?}

... en el fondo del mar ¡matarile, rile, rile, ro, chimpún! Cantábamos de niños ese estribillo de una canción infantil que se solía escenificar en un juego sin preguntarnos qué significaba. Un magistral escrito del Profesor Federico Corriente nos ilustra que proviene del árabe andalusí: ma tarí li, ríli, ríli, rúd, jíd, bún, o sea, 'lo que vas a adivinar, adivínamelo, adivínamelo, contesta, (ya está) bien, bueno’ ${ }^{1}$. Sin prisas.

* www.tirocinio.com // pilar@tirocinio.com.

${ }^{1}$ Federico CORRIENTE, «Arabismos en la cultura popular española», $<$ https://funci. org/arabismos-en-la-cultura-popular-espanola> (2011) [Consulta: septiembre 2019].

Copyright: (C) 2020 CSIC. Este es un artículo de acceso abierto distribuido bajo los términos de la licencia de uso y distribución Creative Commons Reconocimiento 4.0 Internacional (CC BY 4.0). 
Me decidí a emprender esta aventura porque de un tiempo a esta parte han llegado numerosos mensajes al chat virtual en judeoespañol Ladinokomunita: unos, constatando la existencia en ciertas familias sefardíes de unas llaves que sus antepasados habrían llevado consigo en su partida de la Península Ibérica en 1492 y que se habrían transmitido de generación en generación; otros, aseverando que nunca supieron de tales llaves $^{2}$. Llaves, ¿sí o no?

En buena lid, se preguntaba Rachel Amado en su mensaje de 4/1/2018:

Mezmo muestra kerida «nona» ['abuela'] la talentuoza muzikante Flory Jagoda, kompozo i enrejistro una kantika yamada «La Yave de Espanya», ma nunka le demandi a eya si verdadmente en su kaza avia una yave «en kashon» ke sus «nonos la trusheron kon grande dolor de su kaza d'Espanya, d'Espanya», komo dize en la kantika.

Flory Jagoda, cantautora sefardí oriunda de Sarajevo (1926), compuso esa canción que actualmente incluyen en su repertorio numerosos cantantes y grupos musicales. De ella existen varias versiones en youtube $^{3}$ :

Onde esta la yave ke estava in kaxun ['cajón']

Onde esta la yave ke estava in kaxun?

Mis nonus ['abuelos'] se la truxerun kon grande dolor, de su kaza de Espanya, de Espanya.

Nací en el seno de una familia que no atesora periplos transnacionales, pero que lo ha guardado todo como oro en paño. En la casa familiar hay no una, sino varias cajas repletas de llaves. La mayoría de hierro, como se usaban hasta las últimas décadas del siglo pasado. Otras, más modernas, pues el siglo xx vio desarrollar nuevos sistemas de cierre que dieron lugar a una gama de llaves muy variada. Estoy convencida de que las guardaban por inercia. A bote pronto, me resulta incitante ese empecinamiento sefardí e hispano de transmitir de generación en generación las llaves de las casas de España. O, a lo mejor, es algo genético, que propicia un ensoñamiento

${ }^{2}$ Los textos que se aducen en judeoespañol están en caracteres latinos; respetamos su grafía. También respetamos los que están escritos en español antiguo o en otras lenguas, según su grafía original.

3 Véase <https://www.youtube.com> [Consulta: agosto 2019]. 
placentero y confortable. Sea lo que fuere, las líneas que siguen podrían servir a algunos para mantener el vaporoso encanto del mito, y a otros para desincentivar su exitoso cultivo romántico.

\section{TRES TÓPICOS SOBRE LOS SEFARDÍES}

La lengua, la frase del sultán Bayaceto y la llave son tres de los tópicos más extendidos que acompañan las narraciones en torno a la expulsión de los judíos de la Península. Forman parte del imaginario hispano-sefardí. A ellos se hacía referencia de pasada en el artículo «Sefarad, ¿la "patria" de los sefardíes?» ${ }^{4}$.

Los investigadores, entre ellos Iacob M. Hassán, Elena Romero, Paloma Díaz-Mas, y yo misma ${ }^{5}$, llevamos décadas explicando que los sefardíes no «conservaron» la lengua española por «amor» o por «nostalgia» de la tierra que dejaron atrás, sino porque era un elemento que les aglutinaba en la diáspora y les diferenciaba de los pueblos del entorno.

El argumento del «amor» es el más utilizado por quienes pretendían demostrar que los sefardíes guardaron siempre una inquebrantable adhesión a España. Pero se ha demostrado fehacientemente que incluso ellos mismos consideraban que no fue así, sino que lo hicieron por amor a sí mismos. Por ejemplo, en un manifiesto de enero de 1900 de la Sociedad La Esperanza de Viena, en el periódico de tendencia sionista en judeoespañol El Progreso, fundado en 1899 con la intención de defender los intereses de los «israelitas españoles», se plantea el problema de la defensa y mejoramiento del «español», y lo expresa claramente:

${ }^{4}$ Pilar Romeu, «Sefarad, ¿la "patria” de los sefardíes?», Sefarad 71:1 (2011) págs. 95-130.

5 Iacob M. Hassán, «Los sefardíes como tópico», Raíces 1 (1986) págs. 32-38; «Una cultura que muere. Los sefardíes o el mantenimiento de la identidad hispana en el exilio», El País (Madrid) 26/3/1992; «Realidad y fantasía en las relaciones recíprocas Españasefardíes», en España en la cultura hispánica en el sureste europeo, ed. Juan GonZÁLEZBArba (Atenas: MAE, 2000) págs. 355-369; Elena Romero, «El tema de España en la literatura sefardí contemporánea», en El legado de Sefarad, comp. Norbert ReHRMANN (Salamanca: Amarú, 2003); Paloma Díaz-Mas, Los sefardies: Historia, lengua y cultura (Barcelona: Riopiedras, 2006); RoMEU, «Sefarad». 
Dunque no por amor de Espana (sic), absolutamente no; sino por amor de nosotros mismos, por amor de nuestra existencia y por amor del judaismo debemos SOSTENER LA LENGUA ESPANOL (sic) que nuestros padres hablaban y que nosotros aprendemos desde la más tierna edad como nuestra lengua madre!! ${ }^{6}$

De las discusiones en la prensa sefardí sobre qué lengua deben adoptar los sefardíes se ha ocupado Romero en dos artículos de $2010^{7}$.

También de incierta concreción es la frase que supuestamente pronunció el sultán Bayaceto II (1447-1512) al recibir a los sefardíes en Oriente en 1492 -con la que se probaría la valía de los sefardíes-, y que adujo Gonzalo de Illescas (1518-1583):

Y ansi dizen que Bayazetes (que viuia quando estos Iudios se fueron a sus tierras) solia dezir (quando le alabauan a los Reyes Catholicos de muy prudente y discretos) Yo no se, como los Reyes de España son tan sabios, pues tenian en su tierra, tales esclauos como estos Iudios, y los echaron della. Lo qual acrescienta mucho el loor del sanctissimo zelo destos bienauenturados Principes que por el premio eterno, menospreciaron el prouecho temporal, en tiempo que no les sobrauan muchos dineros ${ }^{8}$.

Esta frase la reprodujo José Amador de los Ríos para la historiografía moderna: «¡Este [Fernando de Aragón] me llamáis el rey político, que empobrece su tierra y enriquece la nuestra!» ${ }^{9}$, así como otros muchos intelectuales españoles ${ }^{10}$.

6 Ángel Pulido, «Los judíos españoles y su idioma castellano», La Ilustración Española y Americana (Madrid) 22/2/1904, págs. 106-110: 107.

7 Elena Romero, «La polémica sobre el judeoespañol en la prensa sefardí del Imperio otomano: materiales para su estudio», en Los sefardies ante los retos del mundo contemporáneo: Identidad y mentalidades, eds. Paloma Díaz-Mas y María SÁnchez PÉREZ (Madrid: CSIC, 2010) págs. 55-64; y «La polémica sobre el judeoespañol en la prensa sefardí del Imperio otomano: Más materiales para su estudio», Sefarad 70:2 (2010) págs. 435-473.

${ }^{8}$ Gonzalo de Illescas, Segunda parte de la Historia Pontifical y Catholica (Salamanca: Vicente de Portonariis, 1573) pág. 147r.

9 José Amador De los Ríos, Historia social, política y religiosa de los judios de España y Portugal (3 vols., Madrid: T. Fortanet, 1875-1876) vol. III pág. 419.

10 Véase también Antonio Sánchez Moguel, (ed.), «Los judíos españoles en el Imperio austriaco y en los Balkanes», Boletín de la Real Academia de la Historia 45 (1904) págs. 205-287: 216, aunque yerra de sultán, pues la atribuye a Solimán. 
En el enunciado de Illescas se contiene, además, otro de los grandes tópicos convertido en mito que se desarrollará a lo largo del siglo XIX: el declive del imperio español debido a la pérdida de «sus judíos», quienes dejaron forzosamente de contribuir a engrandecerlo. La emblemática y profusamente divulgada frase de Bayaceto aparece como recurso literario, con diversas variantes, en numerosas memorias de los sefardíes.

Más incierto aún es que se llevaran las llaves de sus casas de la Península -con lo que demostrarían aún más su querencia por el lugar que dejaron atrás-, teniendo en cuenta, además, que muchas propiedades fueron vendidas, subrogadas, traspasadas a otras familias o requisadas por la Inquisición ${ }^{11}$. En este último tópico centraré esta contribución.

\section{El Simbolismo de las Llaves}

El simbolismo de las llaves era conocido entre los judíos porque Isaías lo empleó cuando dijo Dios a Eliaquim (Is 22:22): «Y pondré la llave de la casa de David sobre su hombro. Y abrirá, y nadie cerrará. Y cerrará, y nadie abrirá».

Las llaves son también símbolo del papado en la Iglesia católica. No en vano Jesús se las dio a Pedro (Mt 16: 18-19): «Y yo te digo: "Tú eres Pedro, y sobre esta piedra edificaré mi iglesia, y el poder de la Muerte no prevalecerá contra ella. Yo te daré las llaves del Reino de los Cielos. Todo lo que ates en la tierra, quedará atado en el cielo, y todo lo que desates en la tierra, quedará desatado en el cielo"». Por ese motivo los escudos de armas del Papa, de la Santa Sede y de la Ciudad del Vaticano tienen las llaves cruzadas como insignia.

Las llaves son en sí mismas símbolo de autoridad. Poseerlas significa dominar lo que encierran. Mediante la entrega de llaves se daba posesión de las ciudades amuralladas o fortalezas medievales a los conquistadores. De ahí esa distinción honorífica que actualmente se otorga en mu-

11 Véase Amador de Los Ríos, Historia social, política y religiosa, vol. III págs. 306309 y 390: «vender, trocar ó enajenar libremente sus bienes muebles y raíces exceptuadas, sin embargo, las sinagogas...», lo que provocó que muchos municipios e iglesias las expropiaran, $\mathrm{y}$ «se estaban apoderando, por medio de los procesos inquisitoriales, de las heredades y bienes de los conversos». 
chas ciudades del mundo a grandes personajes, miembros eminentes de la comunidad o visitantes ilustres: la entrega de las llaves de la ciudad. Se supone que la ceremonia más antigua a este respecto es la de la ciudad de Londres, que data de $1237^{12}$; y una de las más emblemáticas es la entrega que de ellas hizo a los monarcas cristianos el último rey moro de Granada, Boabdil el Chico.

Para los sefardíes, la llave se erige en el símbolo que les une con su pasado histórico en tierras hispanas $\mathrm{y}$, como tendremos oportunidad de ver, la literatura al respecto es abrumadora.

Con todo, debemos atender a las reflexiones de Moshe Shaul, expresidente de la Autoridad Nasionala del Ladino (Israel) y académico correspondiente de Israel de la Academia Nacional del Judeoespañol, quien ya desde las últimas décadas del siglo pasado viene reiterando que «es un tópico lo de que cada sefardí guarda aún la llave de la casa que sus antepasados tenían en Toledo ${ }^{13}$, entre otras cosas, como secundaba Iacob M. Hassán, porque: «es imposible que Toledo tuviera tantas casas para que cada sefardí guarde colgada una llave. Es absolutamente imposible» ${ }^{14}$, y remataba José Luis Lacave: «se puede recorrer una judería de Bucarest, por ejemplo, hablar con un judío, y te citará Toledo. Para ellos, todos vienen de Toledo. Parece que no vivían en ningún otro sitio más que en Toledo» ${ }^{15}$.

Shaul, en su reciente artículo en El Amaneser, el único periódico en judeoespañol existente en la actualidad, pone el dedo en la llaga: 1) en su casa, de probada ascendencia sefardí, no las había; 2) se pregunta

12 Véase $<$ https://www.cityoflondon.gov.uk/about-the-city/history/Pages/freedomof-the-city.aspx> [Consulta: octubre 2019].

13 Moshe Shaul en la entrevista de Miguel BAYón PeredA, «La primera gramática de lengua judeoespañola se publicará en 1992», El País, Cultura (Madrid) 7/10/1991.

14 Iacob M. Hassán, en una de sus intervenciones en las Actas del Seminario internacional España-Israel: Horizonte de un reencuentro. Toledo, del 12 al 14 de septiembre de 1985 (Albacete: Asociación de Periodistas Europeos; Junta de Comunidades de Castilla-La Mancha, 1988) pág. 76.

15 José Luis Lacave, «Los judíos en la España medieval», en Actas Seminario internacional España-Israel: Horizonte de un reencuentro. Toledo, del 12 al 14 de septiembre de 1985 (Albacete: Asociación de Periodistas Europeos; Junta de Comunidades de Castilla-La Mancha, 1988) págs. 7-23: 22. 
sobre las pruebas concretas de su existencia; y 3) no se ha hecho ningún estudio serio al respecto:

Avlando frankamente devo dizir ke en mi kaza no teniamos ninguna yave antigua, $\mathrm{i}$ onde mis parientes $\mathrm{i}$ amigos tambien no vidi nunka una yave semejante; ma la kestion no es si yo personalmente vidi o no una de estas yaves. Lo importante es de saver si ay personas ke las vieron o ke tienen provas konkretas de sus egzistensia. A lo ke yo sepa no fue echo ningun estudio, dokumentado kon provas seriozas, ke permeta de dar una repuesta klara i objektiva a este sujeto ${ }^{16}$.

Trataremos de ver cómo hemos llegado hasta aquí.

\section{EL NACIMIENTO DEL MITO DE LA LLAVE SEFARDÍ}

El nacimiento del mito en clave sefardí tiende sus raíces en lo universal. Es tan prolijo que no puede resolverse en unas pocas páginas, pero intentaré a vuelo de pájaro darle una explicación.

Las crónicas más antiguas, de autores coetáneos o inmediatos a la expulsión, no detallan más que de modo general los bienes que los judíos llevaron consigo, pero en ningún caso mencionan las llaves de las casas. Entre quienes escriben sobre ello hay más judíos que cristianos, tal vez debido a que los cronistas hispanos dedicaron sus esfuerzos mayormente a la narrativa de la conquista de América, como Hernando del Pulgar, Alonso de Santa Cruz, Bartolomé de Las Casas. En cambio, sí aportan información precisa de las penalidades que sufrieron ellos mismos o sus familias, ya desde el momento en que supieron que abandonarían esas tierras, cuando afanosamente procuraron vender o permutar sus propiedades.

Así lo constatan Andrés Bernáldez, el Cura de los Palacios (14501513), y Eliyahu Capsali (ca. 1485-1555), en sus respectivas crónicas, de los Reyes Católicos y de la expulsión:

Ovieron los christianos sus faciendas mui muchas é muy ricas casas, é heredamientos por pocos dineros, é andaban rogando con ellas,

\footnotetext{
16 Moshe Shaul, «Las yaves de las kazas en Espanya de los sefaradis», El Amaneser (Istanbul) 168 de 13/2/2019.
} 
e no hallaban quien se las comprase: é daban una casa por un asno, é una viña por poco paño o lienzo, porque no podian sacar oro ni plata. Empero es verdad que sacaron infinito oro, e plata escondidamente, é en especial muchos ducados, é cruzados abollados en los dientes, que los tragaban, é sacaban en los vientres [...], é en especial las mugeres tragaban mas ${ }^{17}$,

[...] afin que chacun abandonne, parmi ses biens les plus précieux, une part du montant suffisant pour couvrir ses taxes foncières et ses impôts divers. Les biens se révélèrent suffisants ${ }^{18}$.

En iguales términos se pronuncian Šelomó ibn Verga (ca. 1460-1554), Yosef Ha-Kohén (1496-1575), y Samuel Usque (1521-ca. 1596), por poner algunos ejemplos ${ }^{19}$.

Encontramos datos sobre la existencia de judíos sefardíes en tierras orientales previa a la expulsión, entre otros, en el relato de viaje de 1489 de 'Obadiá de Bertinoro: "conmigo estudian permanentemente dos alumnos sefardíes» ${ }^{20}$. Es probable que se trate de judíos originarios de la Península Ibérica llegados para estudiar en Tierra Santa, o quizás miembros de las familias huidas de la zona levantina peninsular en 1391, año que marcó el cénit de un siglo muy cruento contra los judíos y que finalizó con masivos asaltos a las juderías. A resultas de ello, muchas comunidades, como la de Barcelona, fueron arrasadas, y sus miembros se dispersaron. Poco después de 'Obadiá, en 1495, un discípulo suyo constataba el inusitado aumento de la población jerosolimitana:

17 Andrés Bernáldez, Historia de los Reyes Católicos D. Fernando y D. ${ }^{a}$ Isabel: Crónica inédita del siglo XV, escrita por El Bachiller Andrés Bernaldez, Cura que fue de los Palacios, 2 vols. (Granada: Imprenta y librería de D. José Maria Zamora, 1856) vol. 1 pág. 254.

18 Eliaohu Capsali, Chronique de l'Expulsion. Seder Eliahou Zouta (Paris: Éditions du Cerf, 1994) págs. 103-104.

19 Véase María José CAno, (ed.), Selomoh ibn Verga. La Vara de Yehudah (Barcelona: Riopiedras, 1991) págs. 216 y ss.; Pilar León Tello, (ed.), Yosef Ha-Kohen. El valle del llanto (Barcelona: Riopiedras, 1989) págs. 118 y ss., y Samuel Usque, Consolaçam ás tribulaçoens de Israel (3 vols., Coimbra: Amado, 1906) vol. 1, págs. Xxv y ss.

20 José Ramón Magdalena, Relatos de viajes y epístolas de peregrinos judios a Jerusalén (Sabadell: Ausa, 1987) pág 146. 
[...] en el año de la expulsión de España [...] a mi llegada aquí me cansé buscando casa para instalarme, pues han aumentado los que han venido a la ciudad y el país entero está lleno de gentes ${ }^{21}$.

Magdalena aclara que estas «gentes» llegadas a Jerusalén son judíos sefardíes expulsados en 1492. Ni que decir tiene que las noticias son tan breves en estos libros de viajes que la mención de una llave cualquiera resultaría ficticia en el contexto.

A mediados del siglo XVI, sus descendientes se hallan instalados en las urbes otomanas ejerciendo de súbditos probos. Entre ellos, y como más conocidos, los próceres Yossef y Gracia Nassí; el médico personal de Solimán el Magnífico, Moisés Hamón; y el rabino de la comunidad catalana de Salónica, Moisés Almosnino, quien en sus crónicas tampoco menta llave alguna ${ }^{22}$.

El siglo XVII es de un profundo silencio en la literatura sefardí oriental. No se conoce ni una sola obra producida en lengua romance por sefardíes. Seguramente debió existir una continuidad entre la producción literaria de los judíos expulsos y la eclosión de la literatura sefardí que se produce en el siglo XVIII, pero lo cierto es que no ha quedado de ello resto alguno conocido hasta la fecha. De ese siglo es la crónica en hebreo de Yosef Sambari (ca. 1630-ca. 1700), que finaliza su relato con la aparición del «astro luminoso» de los otomanos, bastante antes de la expulsión, «y de su genealogía que se engrandeció por medio de un sueño» ${ }^{23}$.

${ }^{21}$ Magdalena, Relatos de viajes, págs. 159-163.

22 Véanse Gilles Veinstein, «El Imperio otomano, desde 1492 hasta finales del siglo XX», en Los judios de España. Historia de una diáspora, 1492-1992, ed. Henry Méchoulan (Madrid: Trotta, 1993) págs. 347-372: 358-363, y Pilar Romeu, (ed.), Moisés Almosnino. Crónica de los reyes otomanos (Barcelona: Tirocinio, 1998).

${ }_{23}$ Maria Esperança Barjau i Rico, (ed.), El Séfer Divré Iossef de Iossef ben Isaac ben Sambari (Barcelona: Universitat, 1996) pág. 143. Sobre las diferentes etapas de creación de la literatura sefardí a través de los siglos y sus contenidos es necesario consultar los varios estudios de Elena ROMERO, «Generalidades acerca de la literatura judeoespañola», en Los sefardies: Cultura y Literatura, ed. Paloma Díaz-Mas (San Sebastián: Servicio Editorial, Universidad del País Vasco, 1988) págs. 87-102; «Die Sephardische Literatur in Judeoespañol - Historische Entwicklung und Literarische Genera», Kairos (Salzburgo) 30-31 (1988-1989) págs. 82-93; La creación literaria en lengua sefardí (Madrid: Mapfre, 1992); «Literatura sefardí de transmisión escrita», en Actas del Simposi Internacional sobre Cultura Sefardita (Barcelona: PPU, 1993) 
Tampoco el anónimo autor del Sipur debarim (Constantinopla 1728), que bebe en la obra de Sambari, menciona las llaves en el epígrafe titulado en la versión judeoespañola de Constantinopla 1767 «La expulsión de los judíos de Sefarad», pero precisa que: «dejaron sus bienes y sus haberes en poder de sus enemigos» ${ }^{24}$.

Lo más cercano a un libro histórico un poco más allá es el Séfer Yosipón o Séfer Yosef Bin Gorión, originalmente escrito en hebreo bíblico, que relata principalmente la historia del pueblo judío en el período del Segundo Templo y la guerra de los judíos contra los romanos, pero no llega tampoco a la época de la expulsión, por lo que mal podría hablar de llaves ${ }^{25}$.

\section{Del mito de la lengua Al mito de la llaVe}

El mito de la llave no apareció de modo súbito, sino que fue propagándose subliminalmente desde principios de siglo XIX mientras iban apareciendo informaciones sobre los judíos o «israelitas», en general, en diversas publicaciones, y se mentaban en las sesiones del Senado y de

págs. 119-139; «La literatura sefardí: de la tradición a los tiempos modernos», en $L a$ memoria de Sefarad: Historia y cultura de los sefardies, coord. Pedro M. PIÑERo RAMÍREZ (Sevilla: Fundación Sevilla NODO - Fundación Machado, 2007) págs. 173-205; «La influencia de la Biblia en la literatura judeoespañola de los Balcanes», en La Biblia en la literatura española: vol. II, Siglo de Oro, dir. Gregorio Del Olmo Lete, coord. Rosa NAVARro Durán (Madrid: Trotta - Fundación San Millán de la Cogolla, 2008) págs. 289-313; «Historia y literatura», en Sefardies: Literatura y Lengua de una Nación Dispersa, ed. Elena Romero, coords. Iacob M. Hassán y Ricardo IzQUiERdo Benito (Cuenca: Ed. de la Universidad de Castilla-La Mancha, 2008) págs. 155-192; «Literatura sefardí: una breve visión de conjunto», en Historia de la literatura hebrea y judía, dir. Guadalupe SeIJAS (Madrid: Trotta, 2014) págs. 843-874; «Sin traje de luces y a la arena», en Voces hispanas nacidas en el exilio: Textos y estudios de literatura sefardí, Homenaje a Iacob M. Hassán (ź’l), ed. Elena Romero (=eHumanista 28 [2014]) págs. VI-XI.

24 Aitor García Moreno y Moisés Orfali, La saga de los reyes otomanos (Granada: Universidad, 2018) págs. 19-21 y 124-125.

${ }^{25}$ Esta fue una de las obras clásicas hebreas del género de la prosa histórica de la que más traducciones se hicieron en judeoespañol (Constantinopla 1743, Salónica, 1863 y 1890, Esmirna, 1876 y Jerusalén, 1902 y 1908). Véase Moisés OrfaLI, «Ediciones en ladino del Séfer Yosipón», Boletín de la Real Academia Española, vol. XCVI, c. CCCXIV (2016) págs. 661-681: 669. 
las Cortes tanto como en las de otras instituciones. Lentamente fue brotando una corriente propicia en España hacia los sefardíes que acabó cristalizando, no en la campaña de Ángel Pulido, sino décadas antes, como señala Díaz-Mas:

En general, suele considerarse que ese filosefardismo español nace con la campaña emprendida por el senador Ángel Pulido Fernández a principios del siglo xx [...] Sin embargo, ya desde la década de 1870, en la prensa liberal española encontramos informaciones y artículos sobre los sefardíes, que proponen las mismas ideas e iniciativas que años después difundirá y defenderá Pulido ${ }^{26}$.

Añadiré: incluso antes. He constatado que hay noticias sobre los sefardíes desde principios de siglo, especialmente sobre su lengua, en los periódicos españoles digitalizados por la Biblioteca Nacional de España, disponibles online ( $<$ http://hemerotecadigital.bne.es $>)$, que comienzan a propagar el mito de la lengua desde los reinados de Fernando VII (1808-1833) y de Isabel II (29/9/1833-30/9/1868) ${ }^{27}$ :

No es posible desarraygar del todo las reliquias de un antiguo pueblo como el judío, que conserva aun la «lengua española», y se confunde fácilmente con los españoles (El Sensato de Santiago de 11/2/1813).

Pero a la prensa española llegan también recortes de noticias de la prensa internacional, como de La Gaceta de Bayona o El Instructor de Londres:

[...] los turcos han hecho un movimiento de Schumla á Bazarjik [...] Las noticias de las fronteras suelen darlas los judíos de Constantinopla. Hablan una lengua mezclada de turco, hebreo y muchas palabras españolas, porque descienden de los que fueron espelidos de España mas de tres siglos ha (La Gaceta de Bayona de 19/1/1829).

Habiendo entrado en un dia de Sábado, por curiosidad, en una sinagoga en Jamaica, uno de los principales Judíos de aquella congregación nos dio el libro que tenía en su mano $[\ldots]$ á nuestra mayor sorpresa

${ }^{26}$ Paloma DíAz-MAS, «Ramón Menéndez Pidal y la cultura sefardí», en Lengua y cultura sefardi, eds. Nicolás Asensio JiméNeZ y Sara SÁNCHEZ Bellido (Madrid: Fundación Menéndez Pidal-Ramón Areces, 2015) págs. 179-210: 183.

27 Para no entorpecer la lectura, he preferido que las citas a los periódicos antiguos correspondientes vayan tras la acotación y no en nota. 
hallamos que el título era «Preceptos, oraciones y ceremonias de la sinagoga para los Judíos Españoles, impreso en Sevilla años de 5267» correspondiente al año 1506 de la era cristiana (El Instructor de Londres de 12/1834).

Para el tema que nos ocupa, la primera mención de unas «llaves» oriundas de España que he encontrado es de 1859. Las llaves están en posesión de moros, porque es justo en esta época cuando los españoles van a tomar contacto con ellos, y de rebote, con los judíos que viven en Marruecos:

Los moros pretenden que conservan las llaves de Córdoba y de Granada; las primeras en Rabat, y las segundas en Fez. Estos recuerdos [...] se sacan procesionalmente en momentos críticos, y producen el mayor entusiasmo por la guerra (La América. Crónica Hispano-Americana de Madrid de 24/11/1859).

Esta es la época de la campaña africana (1859-1860), pero el Diario de un testigo de la guerra de África de Pedro Antonio de Alarcón (Madrid 1859), quien proporciona bellísimas descripciones de los usos y costumbres de los judíos, que conservan aún rasgos netamente hispánicos, silencia las llaves. Esta primera toma de contacto con los sefardíes supuso el encuentro con la haquetía, la variante dialectal del judeoespañol de Marruecos. Con todo, inmediatamente tras la toma de Tetuán el 6 de febrero de 1860, unas llaves fueron también importantes: las que se entregaron al vencedor general O'Donnell en presencia de la masa enfervorecida, entre la que se hallaban los judíos:

La entrada de nuestras tropas en Tetuan fué verdaderamente triunfal. Casi todos los vecinos judíos salieron á recibir á sus libertadores á las puertas de la ciudad. Una comisión presentó arrodillada las llaves de la plaza al general O’Donnell (El Clamor Público de Madrid de 14/2/1860).

De modo que antes de la Revolución de 1868 se reconocía a los judíos españoles y su lengua (mítica, bella, a veces ininteligible, pero real), pero poco a poco, el habla va a dejar paso a la creación del mito de la llave. La Revolución de septiembre supuso el destronamiento y consiguiente exilio de Isabel II y el inicio del período denominado Sexenio Democrático: primero con la monarquía parlamentaria de Amadeo I de Saboya (2/2/1871-10/2/1873), y luego con la Primera República 
(11/2/1873-29/12/1874), hasta el inicio de la Restauración borbónica (fines de 1874).

En esta segunda mitad de siglo fue fundamental el establecimiento de la libertad de culto. Un mes escaso después de la Gloriosa, la prensa informa sobre la resolución de la petición por parte de judía (Mr. Guedalla) de que se anule el decreto de expulsión:

La prensa francesa publica la respuesta dada por el conde de Reus á la petición hecha por Mr. Guedalla [...] para que se anule el edicto de 20 dé marzo de 1432 que desterraba á los judíos del territorio español. El general Prim [...] dice á la asociacion que deben dirigir su solicitud al gobierno de la nación, quien de acuerdo con las Córtes, hará justicia á los deseos de los israelitas, permitiéndoles vivir en España comó viven en toda Europa (La Época de Madrid de 25/10/1868).

Este fue el primer paso, aunque la declaración supuso acaloradas discusiones entre pro y antijudíos en todos los foros. Con todo, a instancias de los generales Prim y Serrano, el 7 de octubre se constituyó un gobierno provisional, una de cuyas principales medidas fue la redacción de una nueva Constitución en la que se plasmaran las libertades individuales y colectivas del nuevo sistema de gobierno. En enero de 1869 comenzaron a reunirse las Cortes Constituyentes para ratificar el 1 de junio la nueva Constitución, que afirma en su artículo 21:

La nación se obliga á mantener el culto y los ministros de la religión católica. El ejercicio público ó privado de cualquier otro culto queda garantido á todo los estranjeros residentes en España, sin mas limitaciones que las reglas universales de la moral y del derecho. Si algunos españoles profesaren otra religion que la católica, es aplicable á los mismos todo lo dispuesto en el párrafo anterior.

Esta decisión de los liberales suponía romper con el tradicional ensimismamiento de los gobiernos conservadores. Por lo general, los periódicos liberales suelen mostrar una actitud positiva hacia los judíos, y hacia los sefardíes en concreto. Entre 1869 y 1871 destacó en las sesiones de Cortes Emilio Castelar (1832-1899) por sus discursos en favor de la república y de la libertad religiosa ${ }^{28}$.

28 Nitai Shinan, «Emilio Castelar y los judíos», Miscelánea de Estudios Árabes y Hebraicos, Sección Hebreo 65 (2016) págs. 101-118: 104. 
En esta segunda mitad de siglo, son numerosos los artículos y ensayos sobre «las llaves» que abren y cierran, sobre todo espacios geográficos determinantes: Tánger, Gibraltar, Constantinopla. Por ejemplo, Las llaves. Sátira social, de Teodoro Guerrero (Madrid 1876), donde en el primer capítulo analiza la simbología de las llaves de la casa «de hierro toscamente labrada», o Las llaves del Estrecho: estudio sobre la reconquista de Gibraltar, de José Navarrete (Madrid 1883). De ambos libros se hicieron varias reseñas en los periódicos, pero del primero su enjuiciador recalca que las llaves actúan como elemento que transporta la imaginación del autor:

Caprichoso es el titulo: Las Llaves [...]. En la introduccion esplica el autor, despues de consagrar frases muy merecidas á los judíos [...] el objeto primordial que le inspiró el libro, y como, por todas partes se va á Roma, un manojo de llaves que salieron de su cajón sirven de vehículo al filósofo y al escritor, y transportan su imaginación á diferentes lugares y en determinadas situaciones de la vida (Salvador M. de Fábregues en La Ilustración Popular Económica de Valencia de 10/2/1876).

También aparece un encendido y poético artículo sobre las bellezas de Granada, que sigue siendo esencialmente mora, donde las llaves de sus casas se transmiten de padres a hijos:

Ni es tampoco extraño que los descendientes de los que la habitaron se leguen hoy en África de padres á hijos la llave de la casa que en Granada vivieron, cuando era para los creyentes de Mahoma búcaro de uardos, pebete de aromas, la cuna de la luz, el lecho del amor, la ciudad sagrada (Jacinto O. Picon en El Globo de Madrid de 7/6/1875).

Los pogromos de Rusia de 1881 provocaron que el problema judío comenzara a interesar realmente a los intelectuales, a los políticos y a la opinión pública. Tres posiciones políticas se asentaron al respecto en 1881-1882: 1) la de los partidos liberales, que apoyaban la causa judía y el retorno de los sefardíes; 2) la de los conservadores, que aunque condenaban el antisemitismo y veían con buenos ojos a los judíos ricos en España, no estaban a favor de repatriar en masa; y 3) la de la prensa integrista católica y el absolutismo monárquico, que manifestaban un antisemitismo visceral lanzando fuertes críticas al Gobierno liberal por la apertura con respecto a los judíos. 
Por entonces son legión las noticias que van acompañadas del «cariño» y la «nostalgia» que sienten los sefardíes por su «antigua patria», sobre todo resaltando la comunidad de lengua ${ }^{29}$.

En la última década del siglo, las noticias sobre los «judíos españoles» van en aumento. Contribuyó en parte el desarrollo en Francia, entre 1894 y 1906, del Caso Dreyfus, que marcó un hito en la historia del antisemitismo. Las noticias aparecidas en la prensa española al respecto son innumerables, y también de lo que ocurre con otras preciadas llaves «oxidadas» más allá de nuestras fronteras:

En Berlín se conserva una especial colección de recuerdos de la guerra franco-prusiana de 1870-71. Son las llaves, cuidadosamente conservadas, de las principales fortalezas francesas que capitularon durante la guerra. [...] Todas estas llaves están oxidadas por el tiempo (El Correo Español de Madrid de 26/8/1895).

Es la época en que también se publican en los periódicos, por entregas, numerosas novelas románticas de tema judío o con un personaje judío: de Alexandre Dumas (1802-1870), Charles Dickens (1812-1870), Xavier de Montépin (1823-1902), con lo que va abonándose el terreno que harán propicia la conversión del tópico en mito.

\section{6. ¡Llaves! ¡Llaves! ¡Llaves!}

Ya no queda más que encontrar judíos con llaves y, a decir verdad, el siglo xx colma las expectativas. Las llaves se harán plenamente judías al tiempo que irá propiciándose su magnitud: «aparecieron nuestros

29 «[En 1868] aún vuelve los ojos con amor a las tierras donde el sol se pone, y aún habla la lengua de sus perseguidores», apud Emilio Castelar, «El Gueto de Roma», Raíces 40 (1999) págs. 29-35; «En ellos el amor a la patria madrastra es tan vivo como el que tienen al suelo antiguo», apud Benito Pérez Galdós, Gloria (Madrid: José María Pérez, 1877) cap. Xxvi; «Los hebreos de origen español [...] continuaban profesando amor á las costumbres y la lengua de su patria antigua» (Revista Contemporánea de Madrid, n. $\left.{ }^{\circ} 8,3 / 1877\right) ;$ «[...] conservan el recuerdo de su antigua patria, hablan nuestro idioma» (El Día de Madrid de 13/11/1883). 
hombres, seguidos por un judío con una llave muy grande; esta llave era de una casa del barrio judío» ${ }^{30}$.

Con el discurso «El alma española» inauguró Ernst Bark von Schultz (1858-1922) en Madrid «la Sociedad del Librepensamiento». Este romántico revolucionario originario de Estonia (entonces Imperio ruso), recaló en España hacia 1880 perseguido por los zares, se casó con una española y está enterrado en el cementerio de La Almudena. Nadie ha podido determinar si era de origen judío, pero ¡ah!, es el primer personaje que he encontrado que las menciona expresamente:

Hasta las orillas del Dniéper en Rusia he oído cantar á los cosakos al son de la guitarra canciones del Guadalquivir, de Sevilla y Granada, y en las aldeas hebreas de Rumanía y Hungría conservan los patriarcas las llaves de sus casas de que les expulsaron la avidez de los reyes y del clero de España ${ }^{31}$.

A partir de ese momento, la posesión de las llaves se convierte en un tema tópico, recurrente y crecientemente obsesivo, tanto en posesión de moros ${ }^{32}$ como de judíos, mientras los periódicos informan a cada paso de hallazgos de «llaves históricas», como las «de gran tamaño, recubiertas de moho» de la prisión del conde Ugolino que inmortalizó Dante ${ }^{33}$, o del furor coleccionista moderno de llaves que «ha aparecido bajo el nombre de "clavemanía" [...] y que consiste en el deseo irresistible de reunir llaves de todas procedencias, clases, tamaños y formas» ${ }^{34}$.

30 Edwin L. Weeks, «Dos centros de arte morisco: Rabat y Sallee», Por esos mundos n. ${ }^{\circ} 81$ (Madrid) de 1/10/1901, pág. 308.

31 Ernst BARK, «El alma española», Las Dominicales: Semanario librepensador sostenido por las almas luminosas (Madrid) de 28/3/1902.

32 «Los descendientes de aquellos moros granadinos conservan vivo el recuerdo del paso de su raza por nuestra patria, y muchos guardan todavía las llaves y los títulos de propiedad de las casas que tenían en Granada sus ascendientes» («En Tetuán», Alrededor del Mundo de Madrid de 21/11/1902); «Se dice que algunos de los habitantes de Fez conservan aún las llaves de las casas que ocuparon sus antepasados en Sevilla, Granada y Córdoba» («La guerra de Marruecos», La Correspondencia de España de Madrid de $30 / 12 / 1902)$.

33 «Unas llaves históricas», en Alrededor de Mundo de Madrid de 29/9/1904.

34 «¿Es usted clavemaniaco?», en Alrededor del Mundo de Madrid de 4/2/1904. 
El aura de Ángel Pulido (1852-1932) comienza a despuntar al mismo tiempo que el interés por los judíos se re-despierta a nivel mundial debido al pogromo de Kishinev (Rusia) (entre el 6 y el 7 de abril de 1903), que vuelve a poner sobre el tapete la situación de los judíos en Rusia, y como consecuencia acrecienta en España el interés por los judíos que habitan en el Este de Europa. Lo propio aconteció en 1881 cuando el ministro de estado Marques de la Vega de Armijo quiso traer a los judíos rusos a través de Constantinopla. Por entonces llegaron solo unas 50 familias indigentes, lo que provocó una oleada de protestas y críticas a su gestión que se vieron colmadas con florituras que le dedicó la posterioridad: «donosamente le llamó por eso El Siglo Futuro el marqués de todos los judíos del mundo» ${ }^{35}$; «capaz de vender todas las primogenituras posibles por un plato de judías danubianas, con sus judíos correspondientes» ${ }^{36}$.

Ángel Pulido propuso a la Cámara, en un tono manifiestamente lacrimógeno y apelando al sentimiento de los diputados, diferentes cuestiones que atañían a los «judíos españoles de Oriente» ${ }^{37}$ :

[...] navegando por el Danubio en dos ocasiones distintas, una hace veinte años [1883] y otra este verano [1903], oía á varios individuos, procedentes unos de Sofía, Andrianópolis y Philipópolis, y otros de Bukarest y Belgrado, les oía, digo, hablar con una emoción tan intensa, con un estremecimiento de placer y de adoración tal de España, que hasta lágrimas saltaban de sus ojos, recordando los tiempos pasados y oyendo hablar á otros españoles en un idioma que creían que solamente ellos en aquellos sitios poseían.

Poco después, en 1905, Pérez Galdós publicó Aita Tettauen, que constituyó uno de los Episodios nacionales (es la sexta novela de la cuarta serie). Dice Aldina Quintana que cuando la escribió en 1904-1905 ya se había elaborado el discurso español sobre los sefardíes en el que

35 «Teodosio» en la «Sección antimasónica»: «Una judiada», La Lectura Dominical de Madrid de 27/1/1917.

36 Antonio de Valbuena, Ripios aristocráticos (Madrid: Victoriano Suárez, 1906) pág. 40.

37 En el Diario de las Sesiones de Cortes de 13/11/1903. 
quedaba incluido el «amor» a España, aunque pone en duda que la frase que lo caracteriza pudiera salir de la boca de un sefardí en $1860^{38}$ :

Luego, respondiendo a mis exhortaciones para mantener la fidelidad al Mogreb y la confianza en su fuerza, me dijo que los judíos, o no tienen ninguna patria, o tienen dos, la que ahora les alberga y la tradicional: esta es España ${ }^{39}$.

Señala Quintana que lo que más adecuado sería asignársela a uno de principios del siglo xx, cuando la campaña pro-sefardí pulidiana había comenzado a repercutir no sólo en algunos círculos de intelectuales españoles, donde el terreno estaba abonado, sino también en los sefardíes ${ }^{40}$. Por entonces, Pulido había publicado ya sus dos libros: Los israelitas españoles y el idioma castellano (1904) y Españoles sin patria y la raza sefardí (1905) ${ }^{41}$. El mito se popularizó a través de su cita al historiador José Amador de los Ríos:

Dice el ilustre historiador Amador de los Ríos, en su preciosa obra Historia de los judios de España [...] Y que no faltaban algunos que traían las llaves de las moradas, abandonadas por sus abuelos en el momento de la expulsión, suponiendo que puedan existir intactas; de las cuales llaves pudo el historiador adquirir algún diseño ${ }^{42}$.

Llamativamente, esta frase atribuida a Amador de los Ríos no se encuentra ni en sus Estudios históricos, políticos y literarios sobre los

38 Aldina Quintana, «El Mellah de Tetuán (1860) en Aita Tettauen de Benito Pérez Galdós: Cambios de actitud frente a los estereotipos antijudíos en la España de la Restauración», El Prezente 2 (2008) págs. 81-109: 104-105.

39 Benito Pérez Galdós, Aita Tettauen (Madrid: Obras de Pérez Galdós, 1905) 1. ${ }^{\text {a }}$ parte, cap. IV.

40 Véase también Paloma DíAz-Mas, «Repercusión de la campaña de Ángel Pulido en la opinión pública de su época: la respuesta sefardí», en España en la cultura hispánica en el sureste europeo, ed. Juan GonZÁlez-BArba (Atenas: MAE, 2000) págs. 326339.

41 Ángel Pulido, Intereses nacionales. Los israelitas españoles y el idioma castellano (Madrid: Sucesores de Rivadeneyra, 1904), y Españoles sin patria y la raza sefardí (Madrid: E. Teodoro, 1905).

42 Pulido, Españoles sin patria, pág. 214. 
judios de España ${ }^{43}$, ni tampoco en su mencionada Historia social, política y religiosa -que es la obra que cita Pulido-, obras que también he consultado online por mor de que permite búsquedas sistemáticas. Bien hubiera podido mencionarlo Amador de los Ríos de viva voz, o en algún escrito que no he sabido encontrar, pero si ni él ni Pulido crearon el mito, ¿quién fue, con anterioridad a Ernst Bark von Schultz en 1902?

Hay más datos que apuntan a que fue en época un poco anterior. David Melul dejó escrita una anécdota de 1946 cuando visitó Béjar por primera vez. Décadas después habría de fundar el Museo Judío David Melul de Béjar ${ }^{44}$. Allí conoció a Don Juan Muñoz, cuyo primer destino a fines del siglo XIX, una vez finalizada la carrera diplomática, fue la embajada en Bulgaria. Don Juan le narró lo sucedido con un comerciante sefardí en Sofía, y recalca que aconteció «antes de que Ángel Pulido descubriera a los sefardíes en 1903»:

«Kero amostrarle una koza», disho el patron del magazen. En aziendolo alevantar i pasar una chika puerta, lo yevo al interior de una kamaretika. «Era este -konto Don Juan- un lugar intimo kon las paredes kuviertas de numerozos livros en ebreo, bien guadrados i ordenados. En el lugar de onor de esta kamaretika avia un baul de tavla, ke tenia puedeser varios siglos de egzistensia, ke el avrio kon una chika yave, i al interior del kual avia un objeto.

$\mathrm{Al}$ aserkarme al baul pudi ver una grande yave ferojenteada, pozada ensima de finos panyos. Yeno de emosion le demandi ke reprezentava lo ke me estava amostrando, i el, kon una emosion aun mas grande, me respondio:

"Esta es la yave ke mis antepasados tomaron kon si kuando duvieron salir de Espanya; esta es la yave de la kaza onde bivian" ${ }^{45}$.

Sea mucho o un poco antes queda por determinar, pero esta es la segunda mención escrita de las llaves en manos sefardíes. Efectivamente, hemos visto cómo el discurso se ha ido construyendo a base de unas llaves moras cuya posesión, por efecto del amor y de la nostalgia,

\footnotetext{
43 José AMADOR De los Ríos, Estudios históricos, políticos y literarios sobre los judios de España (Madrid: D. M. Díaz, 1848).

44 Véase $<$ http://www.museojudiobejar.com> [Consulta: julio 2019].

45 David Melul, «El reenkontro de dos Bejaranos», en En tierras ajenas yo me vo murir, ed. Gad NAssi (Barcelona: Tirocinio, 2005) págs. 119-121.
} 
se ha extendido a los sefardíes. Sin embargo, una década después, incluso va a ponerse en duda que los moros tengan llaves, pero no se discute que las tengan los judíos:

La leyenda dice cómo hay en Tetuán, en Alcazarquivir y en Larache descendientes de los moros granadinos que conservan las llaves de los domicilios que sus antepasados habitaron en Granada. ¡Bella leyenda que, acaso, no sea más que eso: leyenda! Pero lo legendario, por lo que á los expulsados moros se refiere, es real, referente á los expulsados judíos. Estos conservan la llave de sus casas españolas, y vuelven á sus casas, y con la llave quieren abrir las cerradas puertas (Luis de Oteyza, «Crónica general», La Ilustración Española y Americana de Madrid de $8 / 11 / 1916)$.

En ese momento las citas se multiplican en progresión geométrica y alcanzan no solo al común de los mortales, españoles y sefardíes, sino a relevantes personalidades, como veremos. Para los marroquíes, las referencias de moros y judíos se entremezclan, como evidencian los siguientes fragmentos:

Siguen á los bereberes los moros propiamente dichos, de origen semítico, existiendo mezclados con ellos los descendientes de los arrojados de Córdoba y Granada al terminar la Reconquista, siendo varias las familias que aún conservan llaves y objetos de los palacios que en las ciudades andaluzas habitaron sus descendientes («Marruecos y sus futuros ferrocarriles», Revista Ilustrada de Banca, Ferrocarriles, Industria y Seguros de Madrid de 25/9/1907).

Es Tetuán una ciudad muy moruna [...] 8,500 son judíos y unos 850 europeos, en su mayor parte españoles. Muchos de los moros son descendientes de los expulsados de España, lo mismo también que los judíos; conservan aún bastante bien la lengua castellana y llevan apellidos españoles, habiendo algunos que guardan todavía las llaves de sus casas de Granada y las tienen como oro en paño (Fr. A. Muiños, «Tetuán», $L a$ Hormiga de Oro de Barcelona de 22/4/1911).

[...] como los judíos de Xauen, eran de una hospitalidad hidalga [...] en Tetuán y en Xauen conservan las llaves de las casas que sus remotos antepasados vivieron en Córdoba (Diario de Las Palmas de Las Palmas de Gran Canaria de 13/12/1924).

A lo largo del siglo xx, otros muchos ilustres científicos, escritores e investigadores se hacen eco en sus obras, en una $u$ otra forma, con citas segu- 
ramente dichas en clave poética, del seductor atractivo de las llaves, contribuyendo a consolidar el mito. Voces relevantes como las de Barón de la Rábida $^{46}$, Joseph Perez ${ }^{47}$, Julio Jiménez Rueda ${ }^{48}$, Rafael Cansinos Assens ${ }^{49}$,

46 «Por boca del señor Alcheh nos enteramos del curioso concepto que conservaban de nosotros sus hermanos de Salónica [...] sus abuelos, aquellos que llevaron consigo las llaves de sus hogares de Granada y Toledo, que hoy conservan los nietos a quienes el amor a nosotros empuja ahora a la que para sus almas ha seguido siendo su patria» (La Ilustración Española y Americana de Madrid de 30/12/1916). También Paloma DíAz-MAs («La visita a España de Isaac Alcheh y Saporta (1916) y su repercusión en la prensa española», en Caminos de leche y miel. Jubilee Volume in Honor of Michael Studemund-Halévy, 2 vols., vol. II: Language and Literature, eds. David M. BunIs, Ivana Vučina Simović y Corinna DepPner [Barcelona: Tirocinio, 2018] págs. 315-333) aporta información sobre el personaje y las noticias que generó la visita a España en 1916 de Isaac Alcheh y Saporta. Pero hay más ejemplos: «[...] Max Nordau. Habla castellano con tonalidad dulce y uso gracioso de palabras arcaicas. Había vuelto a visitar la casa que en Segovia tenían sus antepasados. De aquella morada conserva las llaves» (Roberto Castrovido, «La sinagoga de Madrid», La Voz de Madrid de 27/7/1921); «se dice que muchos de los que en 1492 fueron expulsados de sus hogares llevaron entre lo poco que les era permitido, el llavín de sus casas [...] Muchos de estos sefarditas del Balcán y del Oriente nos alargan, como un manco su muñón, este llavín; pero ya no existen las cerraduras que les corresponden, ni las puertas en que estaban colocadas las cerraduras y menos las casas que se guardaban con esas puertas» ([firmado por] Medina Asara (seudónimo de Máximo José KAHN), «Paseo por el Toledo judío II», en La Gaceta Literaria de Madrid de 1/9/1930); «España no se sustrae a la protesta contra la persecución, que alcanza a muchos de sus hijos, desterrados hace siglos, pero que aun guardan con conmovedora veneración la llave del solar del "ghetto" toledano y abulense» («Dos días entre los judíos de Francfort», El Imparcial de Madrid de 1/4/1933).

47 «El periódico [femenino Aspiraciones de Madrid, en 1935] se hace eco de una leyenda muy divulgada: al salir de la Península, en 1492, los hebreos se llevaron las llaves de sus casas; desde entonces, estas llaves se transmiten de unos a otros en las mismas familias, señal de que los judíos nunca han perdido la esperanza de volver», apud Joseph Perez, Los judios en España (Madrid: Marcial Pons, 2013) pág. 312.

48 «En los "ghettos" del Oriente se recitan los romances que cantaban los ciegos por las calles de Toledo, Sevilla o Valladolid, y en lugar visible está la llave de la casa abandonada», apud Julio JimÉnez Rueda, Herejías y supersticiones en la Nueva España (México: Imprenta Universitaria, 1946) pág. 83.

49 «Anhelaba [...] una restitución de la tierra y de los tesoros usurpados [...] para entregar un día las llaves de este suelo sagrado a los descendientes de los proscritos, cuando retornasen», apud Rafael CAnsinos Assens, Las luminarias de Janucá (Buenos Aires: Candelabro, 1961) pág. 75. 
Arturo Barea ${ }^{50}$, Jorge Luis Borges ${ }^{51}$, Henry Besso ${ }^{52}$, Salvador de Madariaga ${ }^{53}$, Claudio Sánchez Albornoz ${ }^{54}$, Rafael Lapesa ${ }^{55}$, Paloma DíazMas ${ }^{56}$, entre otras, resultan muy ilustrativas del profundo calado del mito en la sociedad.

Siempre hay, no obstante, algún irredento «empeñado» en armar bulla y hacer de su capa un sayo, como el madrileño periodista Gaspar Tato Cumming replicando vivamente a las advertencias antes mencionadas de Moshe Shaul en las Cartas al Director de $A B C$ de Madrid el 4/8/1994: «Es la única [llave] que vi [en Shanghai] [...] Sí existen las "yaves", señor Shaul. No es un tópico».

50 «[...] de España, le echaron de lo que vosotros llamáis la Imperial Toledo y se vino aquí con sus monedas y su llave», apud Arturo BAREA, La forja de un rebelde (Buenos Aires: Losada, 1958) pág. 39.

51 «Abarbanel, Farías o Pinedo, / arrojados de España por impía / persecución, conservan todavía / la llave de una casa de Toledo», apud Jorge Luis Borges, Poema «Una llave en Salónica» (1964).

52 «Al abandonar España, los sefardíes se llevaron con ellos [...] incluso las llaves de las casas de Toledo, Segovia, Murcia, etc., que tuvieron que abandonar doloridamente en 1492», apud Henry V. Besso, «Causas de la decadencia del judeo-español», en Actas del II Congreso de la Asociación Internacional de Hispanistas, eds. Jaime SÁnchez Romeralo y Norbert Poulussen (Nimega: Instituto Español de la Universidad de Nimega, 1967) págs. 207-215: 208.

53 Según Nuria Azancot («El judeo-español, cinco siglos de milagro», ABC Cultural n. ${ }^{\circ}$ 106, de 12/11/1993 págs. 16-19), «Como escribiera Salvador de Madariaga [...] Sin amargura, con la esperanza de regresar algún día, conservaron como un tesoro, junto a las llaves de sus hogares, un legado transmitido de padres a hijos»».

54 «En un vuelo de la imaginación pensé en los judíos españoles emigrados por todas las tierras del Mediterráneo y aun de la Europa heterodoxa -aludo a Holanda- que todavía conservan, a veces, las llaves de sus casas de Toledo, de Sevilla, de Granada», apud Claudio Sánchez Albornoz, Confidencias (Madrid: Espasa-Calpe, 1979) pág. 123.

55 «[...] apego al toledanismo originario, apego tan profundo y añorante como el que hace que no pocos sefardíes conserven las llaves de las casas que sus antepasados habitaron en Toledo», apud Rafael LAPESA, Crisis históricas y crisis de la lengua española: discurso leído el día 14 de abril de 1996 en la recepción pública de D. Rafael Lapesa Melgar y contestación por el Excmo. Sr. D. Pedro Laín Entralgo (Madrid: Real Academia de la Historia, 1996) pág. 54.

${ }^{56}$ En un cuento que publicó en 1973: «[...] en el siglo xv, salieron de Toledo llevando las llaves de su antigua casa», respecto al cual en este particular entonó un mea culpa años después (DíAz-MAs, Los sefardies, pág. 242). 
Es comprensible que algunos piensen que cuando el río suena... Con todo, desde la primera mitad del siglo xx se alzaron voces críticas contra el mito de la llave. Veamos un interesantísimo artículo en el periódico La Lectura Dominical de Madrid de 27/1/1917, firmado por «Teodosio» en la «Sección antimasónica» con el expresivo título de «Una judiada», decía:

Desde que en 1881, cuando subió al poder D. Práxedes Mateo Sagasta, gran comendador del Oriente de España, se suscitó por la masonería la cuestión del regreso a España de los descendientes de los judíos expulsados por los Reyes Católicos, no han dejado las logias la ida por la venida para procurar ese regreso, no individual, sino colectivamente [...] Entonces, es decir, el citado año 1881, se dictó en este sentido una disposición [...]; pero éstos no vinieron, entre otras razones porque pedían que se les pagara el viaje y otras gollerías para las que no logró reunir los fondos suficientes el Oriente de España, interesado en esta seudo repatriación. Como que se trataba de unos pordioseros reclutados por las logias de Salónica de acuerdo con las de España para producir efecto y presentar al gobierno de D. Práxedes como reparador de las tropelías inquisitoriales, y, naturalmente, si no se les pagaba, no tenían para qué hacer el viaje, pues todo eso del recuerdo de España y de las llaves de sus antiguos domicilios que se llevaron sus antepasados al destierro era pura faramalla.

Esta invectiva continúa meses después en la misma gaceta La Lectura Dominical de Madrid de 22/9/1917, también en la «Sección antimasónica» con el título de «Otra vez los sefarditas»:

El incendio de la ciudad de Salónica [agosto 1917] ha vuelto a poner sobre el tapete en las logias masónicas el proyecto de la venida a España de los judíos sefarditas o sefardies [...] una vez realizada la Restauración y elegido D. Práxedes Mateo Sagasta [...] reverdeció la idea de traer a los sefarditas a nuestra patria, y cuando en 1881 se encargó D. Práxedes de la presidencia del Consejo de ministros y tomó la cartera de Estado el marqués de la Vega de Armijo, publicó éste aquel famoso decreto en que se abrían las puertas de España a todos los hebreos, y que le valió ser llamado por cierto escritor zumbón el marqués de todos los judios del mundo. La invitación no surtió efecto porque los judíos que la aceptaron pedían que se les pagase el viaje y hasta que se les reintegrase en las casas que decían ser de sus antepasados, y cuyas llaves afirmaban tener. 
El asunto quedó en tal estado, hasta que dos años después, en 1883, el doctor Pulido, con motivo de los viajes que hizo por Alemania y Austria Hungría, entabló conocimiento con algunos sefardies y suscitó de nuevo la cuestión de la venida de éstos a España en varias cartas que publicó El Liberal. Escaso eco tuvo esta nueva campaña en pro de aquellos judíos, de los que no se volvió a hablar durante veinte años; pero en 1903 volvió el doctor Pulido sobre el mismo asunto, dándole estado parlamentario con el discurso que pronunció en el Senado a favor de los sefarditas.

Más de una década después, El Cruzado Español de Madrid de 6/9/1929, publica otro furibundo escrito firmado por «Aristarkos» criticando a los redactores de dos periódicos que se hacen benevolente eco de la publicación de la segunda edición de Los hebreos en Marruecos (Madrid 1929) de Manuel Ortega, tachándoles de projudíos: Valero Martín de El Heraldo y Cristóbal de Castro de Nuevo Mundo. Contra el primero, dice:

Porque, ¡vamos!, que el Sr. Ortega echa pestes de los judíos en el terreno privado y conversaciones particulares, como todo hijo de vecino que los trata un mes, es más viejo que la luna [...] Y no le dé usted vueltas, Sr. Valero Martin, el Sr. Ortega, de dientes adentro, no clama por la justicia [...] Tampoco podía faltar el toquecito anticlerical de la «triste, antipolítica, injusta y [...] lejana expulsión» [...] El Sr. Valero sentirá eso que dice de «hermanos nuestros que sienten la nostalgia de la ingrata patria perdida», «sangre nuestra», y «espíritu nuestro». Eso de nuestro querrá decir, de los liberales, de los zurdos, de la gente de la cuerda y... ¡vamos, hermanito, que les aproveche el parentesco! Parece que el espíritu de ustedes está preñado, colmado, abundante y henchido de judaísmo. Que no revienten [...] Al Sr. Valero tampoco se le olvidan las llaves iy las encuentra orinientas! ¡Que poco respeto!

Sigue luego una andanada contra Cristóbal de Castro quien, desdichadamente, no mencionó las llaves:

[...] también disparata que es una bendición. Tres millones de judíos españoles, dice, añoran el suelo español. ¿Si no lo sabe el Sr. Castro, con lo culto que es, quien lo va a saber? y lo mismo de la virtud patriótica que les atribuye [...] son tres millones de españoles sin patria, diseminados por el mundo, bajo el anticuado anatema clerical de pueblo deicida [...] Y la patria española, sigue disparatando, debe abrirles los brazos y 
los entendimientos, el comercio y la voluntad, el suelo y el alma. Pero que muy bien; sí, señor; pero que muy bien. Aplausos.

Un último apunte en la cronología de este siglo xx. En 1985 se celebró en Toledo un Seminario internacional cuyas Actas registran las sesiones e intervenciones de los participantes, y en las que hay un par de jugosas intervenciones denostando el tópico: la de Iacob M. Hassán mencionada antes («es imposible que Toledo tuviera tantas casas para que cada sefardí guarde colgada una llave») y la del periodista Luis Carandell:

Y en España existe un tópico manido que repiten todos los periodistas que hacen ocasionales viajes por el Mediterráneo, que dicen siempre encontrar una familia hebrea en Tesalónica, en Alejandría o en El Cairo, que les enseña las llaves de Toledo. Yo nunca he visto a nadie que me haya enseñado las llaves de Toledo. Creo que es un histórico [isí!], un ilustre tópico [isin duda!], que sin embargo expresa ese antiguo encuentro entre españoles y hebreos ${ }^{57}$.

\section{LAS LLAVES DEL SIGLO XXI, COMO LAS LENTEJAS: O LAS TOMAS O LAS DEJAS}

En pleno siglo xxI, es ya imposible erradicar esta concepción romántica profundamente anclada en el imaginario, tanto popular como culto, y tanto entre los españoles como entre los sefardíes.

La literatura divulgativa actual en España es demoledora ${ }^{58}$, pero también el mundo científico se ha interesado por ellas. Actualmente se lleva a cabo en la Universidad de Navarra un proyecto: «Las "llaves"

${ }^{57}$ Luis CARANDELl, «Intervenciones: Historia de un desencuentro», en Actas del Seminario internacional España-Israel: Horizonte de un reencuentro. Toledo, del 12 al 14 de septiembre de 1985 (Albacete: Asociación de Periodistas Europeos; Junta de Comunidades de Castilla-La Mancha, 1988) págs. 59-60: 59.

${ }^{58}$ Como ejemplos, la novela de Elena Moreno, El misterio de la llave (Madrid: Grupo Santillana, 1992); las memorias de Moïse Benarroch, Llaves de Tetuán (s.1.: Babelcube, 2016); la novela de Pepe MeL, La llave sefardí (Córdoba: Almuzara, 2018); o el recientísimo ensayo de Manuel Enrique Mira, La última llave. Retorno a Sefarad, la patria añorada (Sevilla: Ateneo de Sevilla, 2019). 
de Sefarad: una investigación para dar un futuro a la memoria» ${ }^{59}$, que esperamos aporte conclusiones definitivas.

Célebres periodistas, políticos, poetas e investigadores nacionales y extranjeros, como María del Rosario García Flórez ${ }^{60}$, Juan Boni1la ${ }^{61}$, Manuel Vicent ${ }^{62}$, Manuel Cebrián ${ }^{63}$, Blas Moreno ${ }^{64}$, Andrés

59 Dirigida por Anna Dulska, investigadora del proyecto «Creatividad y herencia cultural» del Instituto Cultura y Sociedad (ICS). Véase <https://www.youtube.com> [Consulta: agosto 2019].

60 «Un número importante de familias sefardíes, de manera real en muchos casos y otros como simple leyenda, conservan la llave de la casa que dejaron en España», apud María del Rosario García Flórez, «Españoles judíos, judíos españoles», en Las llaves de las España, eds. Juan Esteban Constaín et al. (Bogotá: Universidad del Rosario, 2008) págs. 79-98: 86.

61 «Me gusta recordar que los sefardíes [...] conservaban las llaves de sus casas confiando en que no tardara el día en que pudieran volver a utilizarlas en las puertas de las casas de las que los echaban», apud Juan Bonilla, «Segundo Panel de Semblanzas. Participantes: Fernando Delgado, Almudena Grandes, Juan Bonilla y Luis Antonio de Villena», en José Manuel Caballero Bonald. Actas del Congreso-homenaje, eds. Josefa Parra Ramos y Ricardo Rodríguez Gómez (Jerez de la Frontera: Fundación Caballero Bonald, 2008) págs. 163-178: 171.

62 «En algunos hogares de Israel, de Estambul y de Tesalónica muchas familias de judíos sefarditas aún conservan la llave de la casa que sus antepasados habitaron en España, su añorada Sefarad [...] A lo largo de cinco siglos esa llave ha pasado de padres a hijos como una herencia simbólica que contiene, a la vez, la fatalidad del destino y la esperanza de un retorno. Hasta ahora solo servía para abrir la propia memoria y también el arca donde se ha guardado el tesoro de una lengua que se negaba a desaparecer», apud Manuel Vicent, «La llave», El País, Opinión (Madrid) de 16/2/2014.

63 «Su abuelo paterno escapó de la I Guerra Mundial y llegó a Argentina en un barco de carga, por lo que tuvo que abandonar bienes, documentos y todo tipo de recuerdos, entre los que se encontraba la llave de la casa que sus antepasados tenían en Toledo. Este hecho confirmaría que fueron muchos los judíos que guardaron sus llaves pensando en el regreso a su amada patria», apud Manuel CeBrí́N, «Regreso a Sefarad cinco siglos después. Diana Caballero, descendiente de sefardíes toledanos...», $A B C$, Opinión (Madrid) de 22/4/2014.

64 «La leyenda más célebre del pueblo sefardí, la referida a las llaves de España, cuenta que, cuando los judíos se vieron obligados a abandonar el país a resultas de la decisión de los Reyes Católicos de expulsarlos en 1492, se llevaron consigo las llaves de sus casas con la esperanza de algún día poder volver», apud Blas Moreno, «Los sefardíes y las llaves de España», El Orden Mundial en el siglo XXI (España: on-line) de $30 / 3 / 2016$. 
Seoane ${ }^{65}$, Ana Isabel Fernández Samper ${ }^{66}$, entre otros, lo proclaman sin ruborizarse. También desde las instituciones estatales ${ }^{67}$. ¿Será cierto? Con todo, con el paso del tiempo se percibe una mayor tendencia a subrayar que se trata de una herencia simbólica.

Como no podía ser de otro modo, en el siglo XXI se han alzado algunas voces críticas. Carlos Carrete, disertando sobre otro de los mitos a desmitificar (el de que el Santo Oficio actuaba contra los judíos), dice jocosamente que: «las pretendidas llaves de las casas toledanas [...] se llevaron con inusitado entusiasmo y melancolía» ${ }^{68}$. Igualmente, Elena Romero ironiza que Enrique Saporta las incorporó a sus memorias, como veremos después, diciendo que fue "sin duda con el propósito de contribuir al cabo de los siglos a aumentar el material ilustrativo del desmitificador artículo de Hassán [1986]» ${ }^{69}$.

Una de las anécdotas más gloriosas es la del mexicano Carlos Zarur, quien durante la celebración del Congreso Internacional «Reencuentro e

65 «La mayoría de ellos no pudieron llevarse casi nada de sus bienes, pero en sus macutos, junto a las llaves de sus antiguas viviendas, marcharon al exilio con un patrimonio mucho más rico, su lengua», apud Andrés Seonne, «En la lengua de Sefarad», El Cultural, Letras (Madrid) de 4/8/2017.

66 Directora general de Turismo, Comercio y Artesanía de Castilla-La Mancha: «Una de las visitas obligadas de los sefardíes es Toledo porque van buscando las huellas de sus antepasados, de su historia... Es algo muy simbólico y muy sentimental», y es que muchos de los descendientes de quienes emigraron con la expulsión del 1492 «conservan las llaves de sus casas, esperando el momento de regresar a Toledo». Véase $<$ http://www.encastillalamancha.es/especiales/ana-isabel-fernandez-samper-y-las-llavesque-unen-a-los-sefardies-cinco-siglos-despues> [Consulta: febrero 2019].

67 «Las llaves, reales y materiales, de sus casas en Sefarad, que llevaron consigo al exilio con la esperanza de volver algún día a su hogar, se han convertido con el paso del tiempo en llaves metafóricas de su nostalgia por la patria perdida y símbolo de su unión con España», «Kastiyos en Sefarad: los sefardíes vuelven a casa», apud Carta de España del Ministerio de Trabajo, Migraciones y Seguridad Social, Panorama (Madrid, 2015). <www.mitramiss.gob.es/cartaespana/es/noticias/Noticia_0109.htm> [Consulta: febrero 2020].

68 Carlos CARrete, «Comunidades judías castellano-leonesas», en Juderías y sinagogas de la Sefarad medieval, coords. Ana María LóPEz Álvarez y Ricardo IzQUIERDo Benito (Cuenca: Universidad de Castilla-La Mancha, 2003) págs. 365-382: 376.

${ }^{69}$ ROMERo, «El tema de España en la literatura sefardí contemporánea», pág. 186. 
historia de la aljama de Zamora» en julio de 2013, llevó para mostrar la llave de la sinagoga que su familia conservaba:

«La llave que conserva mi familia pudo abrir la última sinagoga de Zamora». - ¿Es una costumbre común? -Así es. No podían llevar ni oro ni joyas, por eso metieron en la maleta sus llaves, aunque nunca pensaron que se convertirían en reliquias ${ }^{70}$.

El zamorano Bernardo Alonso replicó contundente tachándole de provocador:

Venir ahora a Zamora Carlos Zarur con una supuesta llave de sinagoga arroñada del siglo Xv, envuelta en satén para ostentarla en un restaurado convento de monjas expulsadas por el susodicho judío católico masón en el siglo XIX, son ganas de enredar. Un gran profesional de antigüedades en plaza, como buen judío y mejor cristiano, puede proporcionarles docenas de esas llaves, con sus cerraduras ${ }^{71}$.

Finalizando 2019, merece la pena teclear en un buscador web «llaves de Sefarad» para verificar su popularidad. Una de las miles de entradas que me devolvió fue la de que en el Festival Murcia Tres Culturas se presentó el 14/5/2019 el libro de Manuel Mira, a la que seguiría un periplo nacional: «Con ese profundo deseo escrito en el corazón sefardí de regresar a Sefarad, su patria siempre añorada, y a la casa de la que celosamente guardaron la última llave».

\section{LAS LLAVES EN LAS MEMORIAS SEFARDÍES}

Los ejemplos de las llaves que hemos ido analizando hasta ahora mezclan textos de españoles y de sefardíes. Para completar este excurso cronológico haré una incursión más apropiadamente sefardí ahondando en la literatura memorialística que ha proliferado en los

70 José María SADiA, «La llave que conserva mi familia pudo abrir la última sinagoga de Zamora», La Opinión de Zamora (Zamora) de 1/7/2013.

71 Bernardo Alonso, Las llaves de Sefarad y de Palestina, en $<$ http://www.alonsofia. com> 8/7/2013 [Consulta: agosto 2019]. 
últimos decenios en todo el mundo ${ }^{72}$, donde anonada la presencia de las llaves.

En las memorias más antiguas, las de los nacidos en la segunda mitad del siglo XIX, no aparece el mito de la llave más que en dos de ellos: José M. Estrugo y Enrique Saporta, aunque son nueve, todos varones. Algunos fueron profesores o investigadores ${ }^{73}$, otros comerciantes ${ }^{74}$, uno policía otomano ${ }^{75}$, otro rabino ${ }^{76}$, y un periodista ${ }^{77}$. Estrugo y Saporta fueron ambos estudiosos del judaísmo sefardí, con obras prestigiosas, pero como tantos otros, se dejaron contagiar por la corriente filosefardí. Ambos escriben sobre las llaves cuando estaba plenamente asentado el mito, en 1933 y 1982:

En octubre de 1922 llegué por primera vez a España [...] Me parecía que iba a encontrar intactas las hermosas moradas [...] cuyas llaves oxidadas había visto alguna vez en las juderías como reliquias de Toledot (Toledo), la Jerusalén sefardita ${ }^{78}$.

${ }^{72}$ Me baso en las memorias, biografías, novelas autobiográficas y testimonios de historia oral publicadas en forma de libro y sobre las que se ha comenzado a fijar un corpus. Véase Pilar Romeu, Guía bibliográfica de memorias sefardies (Barcelona: Tirocinio, 2012) y Guía bibliográfica de memorias sefardies (segunda parte) (Barcelona: Tirocinio, 2019).

${ }^{73}$ De la Alliance Israélite Universelle, como Gabriel Arié (Samocov, Bulgaria 1863 1939), cf. Esther BenBassa y Aron Rodrigue, (eds.), Une vie judéo-espagnole à l'Est: Gabriel Arié (Paris: Les Éditions du Cerf, 1992), y Abraham H. NAvon (Edirne 1864-París 1952), Joseph Pérez (Paris: Les Belles Lettres, 1999) y Tu ne tueras pas (Paris: Les Belles Lettres, 2000); u otras instituciones, como José Meír Estrugo Hazán (Esmirna 1888-La Habana 1962) y Enrique Saporta y Beja (Salónica 1898-París 1984).

74 Léon Aftalion (Lom, Bulgaria, 1893-?), Ce qu'il en coûte d'être juif (Paris: La Pensée Universelle, 1979), y Léon SCIAKY (Salónica 1894-México 1958), Farewell to Salónica. Portrait of an Era (New York: Current Books, 1946).

75 Rafael Chikurel (Esmirna 1869-1940), cf. Henri Nahum, (ed.), Mis memorias. Una vida yena de drama i perikolos. Les Mémoires de Rafael Chikurel (Istanbul: Isis, 2002).

76 Haïm Nahoum (Magnesia 1873-El Cairo 1960), cf. Esther Benbassa, (ed.), Un grand Rabbin Sepharade en Politique 1892-1923. Haïm Nahoum (Paris: Éditions du CNRS, 1990).

77 Avram Benaroya (Edirne 1888-Estambul 1955), $c f$. Rifat N. BALI, (ed.), Avram Benaroya. Un journaliste juif oublié suivi de ses mémoires (Istanbul: Isis, 2004).

78 José M. Estrugo HazÁn, El retorno a Sefarad (Sevilla: Renacimiento, 2010 [1. a ed. Madrid, 1933]). pág. 39. 
Avram Toledo [...] alevantó los ojos. Vido enkolgada a la pare una grande yave ferrojenta. En su tchikes la avia visto en la kaza de su nono $\mathrm{i}$, despues de su muerte, en la kaza de su padre. Este syendo agora muy aedado se la avia dado en guadra. Porke, segun la tradisyon, el bohor era syempre el guadran de esta yave «la yave de muestra kaza de Toledo» ${ }^{79}$.

Buena parte de los autores, para ubicarlas en el tiempo, utilizan el recurso literario de narrar brevemente la historia de la expulsión. Es en ese momento cuando la mayoría menciona el que sus antepasados se llevaron con ellos las llaves de su casa de España:

Komo los Sephardes kuando al 15 sieklo arojados de la Espanya, kon si yevaron solo sus vidas, las yaves de las kadenas de las kazas seradas ${ }^{80}$.

One of my father's cousins, Zimbúl, a hefty woman with a man's mustache, still held the key to her ancestral house in Córdoba, which her family had left four hundred years before ${ }^{81}$.

Voici la clef que mon grand-père Jacob m'a donnée juste avant la cérémonie du henné [...] La clef de la maison de mes ancêtres, qu'ils emportèrent avec eux lorsqu'ils quittèrent l'Espagne ${ }^{82}$.

Otros refieren que la familia las custodiaba celosamente:

Se akodran de las yaves de sus kazas de Toledo, Kordova o Granada, ke los padres gouardavan para ke los ijos no se olvidan el pasado, y también, sin dizirlo, enkavzo ke les suviryan mazal de retornar ${ }^{83}$.

Pero no era locura lo que le embargaba, sino el orgullo de poseer una simple llave de hierro [...] con los cantos redondeados, gastados por las caricias de padres e hijos de tantas generaciones en tantos siglos ${ }^{84}$,

${ }^{79}$ Enrique SAPORTA y Beja, En torno de la Torre Blanca (Paris: Vidas Largas, 1982) pág. 24.

80 Yamila Kolonomos y Jasminka Namiceva, Sinteyas de los sefardes de la Makedonia [en judeoespañol, macedonio e inglés] (Skopje: La komunita djudiya de la Makedonia, 2006) pág. 43.

81 Brenda SERotTe, The fortune teller's kiss (Nebraska: University of Nebraska Press, 2006) pág. 9.

82 Éliette AbÉcassis, Sépharade. Roman (Paris: Albin Michel, 2009) pág. 449.

83 Marcel Cohen, Lettre à Antonio Saura (Paris: L’Échoppe, 1997) pág. 54.

${ }^{84}$ Harry Moreno, Caminando y hablando (2. ${ }^{a}$ ed. Barcelona: Dèria, 2003) pág. 24. 
y que se transmitían, además, de generación en generación:

[...] ese judeo español tan sonoro y musical, que transmitían a sus hijos junto con las llaves de las casas abandonadas en Sefarad ${ }^{85}$.

Certains, de père en fils, se sont transmis la clé de leur maison de Séville ou de Grenade ${ }^{86}$,

e incluso las exhibían en lugar visible en las casas a las que algún día regresarían:

Dans la maison de ses parents comme dans tant d'autres, on détenait la preuve tangible de ce passé. La preuve, c'était la clé. Il [su padre Bohor] l'avait toujours vue là, accroché au-dessus de la porte [...] ses ancêtres avaient fermé la porte de la maison du Léon ${ }^{87}$.

En uno de los muros colgaba una llave grande muy antigua (en la mayoría de las casas de los judíos se podía ver un objeto similar); ésta era el simbolismo de la llave de aquellas casas que dejamos en España y a las que teníamos el sueño de un día regresar ${ }^{88}$.

Todos estos testimonios dan fe de la fuerza expansiva de un tópico convertido en mito de la iconografía sefardí.

\section{De cómo trajinar unas gráVIDAS Llaves Que haN Ganado LEVEDAD}

Llegados a este punto de la historia, se puede concluir que el mito de la llave entre los sefardíes se construye a partir de tres premisas simbólicas en sí mismas: 1) la llave que «abre»... 2) la casa de sus antepasados en algún lugar de la Península Ibérica... 3) a donde algún día retornarán. La literatura en torno a esas llaves nace como un proceso de reconstrucción personal y nacional que liga a los sefardíes con su

85 Vera Nehama, Las turquesas mágicas (Madrid: Hebraica Ediciones, 2011) pág. 25.

${ }^{86}$ Maurice Deunailles, La Mare aux tortues (2. ${ }^{a}$ ed. Paris: L'Harmattan, 2013) pág. 24.

87 Evelyne Lagardet, Un rêve français (Paris: Flammarion, 2007) págs. 110-111.

88 Rafael ArditTi, Caminos de leche y miel (2. ${ }^{\mathrm{a}}$ ed. México: ed. del autor, 2012) págs. 15-16. 
tierra ancestral en el momento que ambos pueblos redescubren sus existencias y se identifican con su pasado.

El imaginario se fraguó con toda probabilidad a mediados del siglo XIX en torno a la Guerra de África (1859-1860), cuando los soldados españoles trabaron conocimiento con los moros y judíos que se decían descendientes de quienes habían sido expulsados de la Península, y se consolidó al calor de las a veces enconadas disputas políticas que se produjeron en España en la segunda mitad del siglo en torno a la libertad de la práctica religiosa, que adquirió carta de naturaleza en la Constitución de 1869.

Las primeras llaves atestiguadas están, en las fuentes escritas, en manos de moros; luego se propagan a los judíos. Cuando el mito está asentado, hay quien duda de si realmente los moros las poseen, pero los judíos, sin duda. Se transmiten, además, de padres a hijos de generación en generación, en una reminiscencia de hondas raíces bíblicas (Éxodo 3:15): «Este es Mi Nombre por siempre y para siempre y esta es Mi memoria de generación en generación», que otorga solidez y carisma a la transmisión y permite guardarlas «como un tesoro».

Al principio son inmateriales, pero poco a poco se empiezan a visualizar: las muestran sus dueños en la mano, en una cajita recamada, «pozada ensima de finos panyos», colgadas de la pared o encima de la puerta, guardadas en un «baul de tavla» o en el caxun de Flory Jagoda...

La llave empieza su periplo modestamente, pero con el tiempo se agranda, es de hierro, ferrojenta ['oxidada'] o «con los cantos redondeados, gastados por las caricias», no importa demasiado, pues de todos modos abrirán las casas, los solares, las viviendas, las casas solariegas $\mathrm{y}$ «las kadenas de las kazas seradas»...

¿Qué podemos esperar ahora, cuando hasta la Red de Juderías las obsequia? ${ }^{89}$ ¿Sería una idea peregrina relanzar oficios artesanales como los de herrero, grabador, pulidor o anticuario, amparados todos ellos bajo

89 «Vas parando en las localidades dentro de la red [de Juderías] y a medida que completas el pasaporte consigues regalos, desde un diario de viaje a una llave que es todo un símbolo: muchas familias judías se llevaron la llave de sus casas al ser expulsados porque tenían la esperanza de regresar», apud Andrés GuERRA, «Volver a Sefarad», La Vanguardia, Cultura (Barcelona) de 30/3/2018. 
un sublime guardasol institucional? ¿O tal vez crear el Museo de las llaves de Sefarad?

Cualquier idea es buena, con la sola esperanza de que cunda la convicción de que las llaves de Sefarad constituyen un preciado talismán depositado en un bellísimo lugar imaginario de memoria, donde podría seguir ilusionando a las gentes de toda condición, como ocurre con tantos relatos clásicos, inmortales, que se han ido incorporando a nuestro acervo cultural más entrañable.

Recibido: $13 / 11 / 2019$

Aceptado: 07/02/2020 